\title{
Occurrence of Two Little Cherry Viruses in Sweet Cherry in Washington State
}

\author{
N. B. Bajet and T. R. Unruh, United States Department of Agriculture-Agricultural Research Service, Yakima Ag- \\ ricultural Research Laboratory, Wapato, WA 98951; K. L. Druffel, Washington State University, Department of \\ Plant Pathology, Pullman 99164; and K. C. Eastwell, Washington State University, Department of Plant Pathology, \\ Irrigated Agriculture Research and Extension Center, Prosser 99350
}

\begin{abstract}
Bajet, N. B., Unruh, T. R., Druffel, K. L., and Eastwell, K. C. 2008. Occurrence of two little cherry viruses in sweet cherry in Washington State. Plant Dis. 92:234-238.

Little cherry disease, one of the major viral diseases of sweet cherry (Prunus avium) worldwide, is associated with either of two closteroviruses, Little cherry virus 1 (LChV-1) and Little cherry virus 2 (LChV-2). Two sets of primers corresponding to a portion of the replicase gene of LChV1 and LChV-2 were used in one-tube reverse-transcription polymerase chain reactions to detect these viruses in total RNA extracts of field-collected sweet cherry tissues. LChV-1 and LChV-2 were detected both alone and in combination in five sweet cherry orchards in Washington State. Sequence analysis of a 240-nucleotide (nt) fragment of the replicase open reading frame (ORF) $1 \mathrm{~b}$ and a 232-nt fragment from a portion of ORF8 and the 3' untranslated region (UTR) of LChV-1 indicated that North American (NA) isolates shared 90 to $99 \%$ nucleotide identity in both genome segments analyzed. In contrast, comparisons of NA isolates to two Eurasian isolates of LChV-1 indicated shared nucleotide identities of 79 to $82 \%$ in the replicase fragment and 89 to $90 \%$ in the ORF8/3'UTR fragment. Sequence variation in the replicase region did not affect detection of LChV-1 in 12 isolates using the replicase-specific primers reported here. This article represents the first report of LChV-1 and LChV-2 in sweet cherry in Washington.
\end{abstract}

In 2005, Washington State had over 11,700 ha planted to sweet cherry (Prunus avium L.) with a total production of 139,000 metric tons representing $55 \%$ of the total U.S. production (34). The acreage of sweet cherry planted in the United States has increased $43 \%$ over the last decade. Generally, about $30 \%$ of the Northwest cherry crop is exported, 40 to $45 \%$ is sold to domestic consumers, and the remaining 25 to $30 \%$ diverted to processing (9).

Sweet cherry is affected by a number diseases caused by viruses and virus-like agents, including little cherry disease (LChD). Fruit from trees expressing LChD symptoms are not fit for the fresh fruit market because they are small and lack flavor, sweetness, and color. This disease occurs in most areas where sweet cherry trees are grown and is a major concern for sweet cherry commercial production (3,21). LChD first was reported in British Columbia, Canada in 1933 and spread quickly throughout British Columbia cherry production areas $(1,3,32,37)$,

Corresponding author: T. Unruh

E-mail: Thomas.Unruh@ars.usda.gov

Accepted for publication 12 September 2007.

doi:10.1094/PDIS-92-2-0234

This article is in the public domain and not copyrightable. It may be freely reprinted with customary crediting of the source. The American Phytopathological Society, 2008. probably due to transmission by the apple mealybug, Phaenacoccus aceris (Signoret), the only known insect vector (22). In British Columbia, cherry production dropped from 680,000 kg in 1947 to $68,000 \mathrm{~kg}$ in 1979 , by which time most fruit did not meet packinghouse standards, largely due to LChD. A sustained LChD eradication program in tandem with control of the insect vector contributed significantly to the resurgence of the cherry industry in British Columbia (3). Other Prunus spp., including several ornamental species, have been shown to harbor one or more of the causal agents of LChD $(3,16,23,24,37)$. LChD also has been reported in the United States (35), Germany $(12,13)$, and other European countries $(14,26,27,29,36)$, as well as Japan (11) and New Zealand (8).

There are currently two recognized members of the family Closteroviridae associated with $\mathrm{LChD}$; these are designated Little cherry virus 1 (LChV-1) and Little cherry virus 2 (LChV-2). Significant amounts of sequence variation have been reported within isolates of $\mathrm{LChV}-1$ and LChV-2, which has led to a potentially confusing proliferation of isolate names (32). $\mathrm{LChV}-2$ is a species within the genus Ampelovirus of the family Closteroviridae, whereas LChV-1 is a distinct species within the Closteroviridae but has not been assigned to a genus (19). The virus reported as LChV-3, isolate LC5 (31), is now considered a strain of LChV-2 (32). The term LChV-4 was used by Bernardy (1) as a tentative name for an isolate of LChV-1 sharing $88 \%$ nucleotide sequence identity with the type isolate of LChV-1; this level of divergence is now recognized as fairly typical among strains of closteroviruses (19).

To date, there is no published information on the occurrence of LChV-1 and LChV-2 in Washington State, a major center of commercial sweet cherry production. In this article, we document the occurrence of LChV-1 and LChV-2 in sweet cherry in Washington using reverse-transcription polymerase chain reaction (RT-PCR) and examine genetic relatedness among $\mathrm{LChV}$ 1 isolates at two small portions of the genome.

\section{MATERIALS AND METHODS}

Virus sources. Sweet cherry samples were acquired from outside the State of Washington under United States Department of Agriculture-APHIS permits and include an isolate from Eurasia and three North American isolates as follows: (i) 98FI10R2, from Turkey, cv. 0090 Ziraat; (ii) BCOS1, from the OkanaganSimilkameen Regional District of British Columbia, Canada, cv. Lambert; (iii) isolate PALa1, from Lancaster Co., PA, cv. Hedelfingen; and (iv) isolate CASJ1, San Joaquin Co., CA, cv. Bing. Isolates from Washington State were collected from symptomatic trees in commercial production orchards and are reported by Washington county and given an arbitrary orchard number (Table 1). Finally, the complete genome of a German isolate of the LChV-1 (12; GenBank accession no. gi|9629708) is referred to here as isolate UW1.2.

Isolation of RNA templates and RTPCR. Total RNA was extracted and purified using a modification of the manufacturer's procedures for RNeasy Plant Mini Kit (Qiagen, Valencia, CA). Briefly, 0.2 to $0.4 \mathrm{~g}$ of leaf midribs or cambium scrapings were placed in a sample bag (Agdia, Elkhart, IN) and homogenized in $2 \mathrm{ml}$ of $3 \%$ 2-mercaptoethanol; $600 \mu \mathrm{l}$ of the extract was transferred to a microcentrifuge tube containing $0.6 \mathrm{ml}$ of RLT, a proprietary lysis buffer containing guanidinium isothiocyanate (Qiagen) (without additional 2-mercaptoethanol), and thoroughly mixed. The rest of the procedure followed the manufacturer's recommendations. Total RNA eluted in water was stored at $80^{\circ} \mathrm{C}$ until use. In some experiments, RNA 
isolated from partially purified virus or double-stranded RNA (dsRNA) also was used as templates. $\mathrm{LChV}-1$ purification followed the procedure of Eastwell and Bernardy (5). Prior to RT-PCR, partially purified virus was treated with proteinase $\mathrm{K}$ and the viral RNA extracted with phenol:chloroform followed by ethanol precipitation (30). The dsRNA was isolated from leaves of $\mathrm{LChV}$-1-infected trees following the method of Eastwell and Bernardy (5). The dsRNA was suspended in $1 \times$ Tris-acetate-EDTA (TAE; $40 \mathrm{mM}$ Trisacetate, $\mathrm{pH} 7.6 ; 1 \mathrm{mM}$ EDTA), stored at $-80^{\circ} \mathrm{C}$, and used directly as a template for RT-PCR.

The primer pair repl-1, consisting of LCUW7090 (forward, 5'-GGTTGTCCT CGGTTGATTAC-3') and LCUWc7389 (reverse, 5'-GGCTTGGTTCCATACATC TC-3'), was designed with Primer Designer version 3.0, based on the published LChV-1 sequence (UW1.2). This primer pair amplifies a 300-bp fragment (nucleotides 7,090 to 7,389) within open reading frame $(\mathrm{ORF}) 1 \mathrm{~b}$ encoding the putative replicase gene $(12,13)$. Two other primer pairs were described previously. Primer pair $3 p-1$, consisting of the primers 16659 (forward, 5'-GTTATAGAATTCACTGCAAGT G-3') and truncated 3EC (reverse, 5'-CACCTTTTATTTTTTATATATGC-3'), amplifies a 276-bp fragment containing the 68 nucleotides (nt) from the $3^{\prime}$ terminus of ORF8 and the first $208 \mathrm{nt}$ of the $3^{\prime}$ untranslated region (UTR) of LCHV-1 (36). Primer pair repl-2 consists of primers LC26L (forward, 5'-GCAGTACGTTCG ATAAGAG-3') and LC26R (reverse, 5'AACCACTTGATAGTGTCCT-3') and amplify 409 bp of ORF1b of LChV-2 (4).

A one-tube RT-PCR protocol was used to specifically amplify either LChV-1 or LChV-2 RNA. Each reaction contained 2 $\mu \mathrm{l}$ of RNA, $12.5 \mu \mathrm{l}$ of $2 \times$ reaction mix (containing $0.4 \mathrm{mM}$ each $\mathrm{dNTP}$ and 3.2 $\mathrm{mM} \mathrm{MgSO}_{4}$ ) (Invitrogen), $0.25 \mu \mathrm{l}$ of each $20 \mu \mathrm{M}$ primer, $1.0 \mu \mathrm{l}$ of SuperScript III/Platinum Taq mix (Invitrogen), and sterile double-distilled $\mathrm{H}_{2} \mathrm{O}$ to bring the total reaction volume to $25 \mu \mathrm{l}$. RT-PCR was carried out in a thermocycler (iCycler; BioRad, Hercules, CA) programmed for 1 cycle at $52^{\circ} \mathrm{C}$ for $30 \mathrm{~min}\left(58^{\circ} \mathrm{C}\right.$ for $\mathrm{LChV}$ 2), then $94^{\circ} \mathrm{C}$ for $2 \mathrm{~min}$ followed by 35 to 40 cycles of $94^{\circ} \mathrm{C}$ for $15 \mathrm{~s}, 48^{\circ} \mathrm{C}$ for $2 \mathrm{~min}$ $\left(53^{\circ} \mathrm{C}\right.$ for $\left.\mathrm{LChV}-2\right), 68^{\circ} \mathrm{C}$ for $1 \mathrm{~min}$, and a final extension step of $68^{\circ} \mathrm{C}$ for $10 \mathrm{~min}$. The products were analyzed in $3 \%$ Nusieve GTG agarose (Cambrex, Rockland, ME) in $1 \times$ TAE buffer, stained with ethidium bromide at $0.5 \mu \mathrm{g} / \mathrm{ml}$, and visualized (Quantity One BioRad Geldoc System; BioRad). For the simultaneous detection of the two viruses, total RNA extracts prepared from the LChV-1 or LChV-2 isolates were mixed in equal volumes (1:1) and a $2-\mu \mathrm{l}$ aliquot was used as template for one-tube RT-PCR. The RT-PCR schedule was slightly modified: the cDNA synthesis step was $58^{\circ} \mathrm{C}$ for $30 \mathrm{~min}$ and the annealing temperature for the $\mathrm{PCR}$ was $53^{\circ} \mathrm{C}$ for 2 min.

Sequence analysis. Various RT-PCR reaction products were resolved in agarose gels, eluted from gels, and purified using the PCR Product Purification Kit (Qiagen), and cloned into pCR2.1-TOPO (Invitrogen) following the manufacturer's recommendations. Plasmids containing inserts of the predicted size were isolated and sequenced at the Washington State University DNA Sequencing Core Laboratory, Pullman. Alternatively, RT-PCR products were sequenced directly in both directions using the same primer pairs used for the amplification, namely the repl-1 or $3 p-1$ primers. Sequences were aligned using ClustalX (33), trimmed to $240 \mathrm{bp}$ within the replicase gene and 232 bp within ORF8/3'UTR, and used for sequence comparisons. The sequences generated from this study have been deposited in GenBank (accession numbers EU049866 to EU049883) with isolate names as described herein. Cladograms were estimated from the sequences, treating them as character state data with the DNA Maximum Likelihood Program, DNAML, of the Phylip Sequence Analysis Package (7), version 3.66, and with the BayesianMarkov chain method as implemented in MrBayes, version 3.1.2. (10). The presented cladograms were created from the neighbor-joining algorithm as implemented in MEGA3, version 3.1 (15), using the Tamura-Nei distance metric, with evolutionary rates allowed to vary between lineages and substitution rates among sites varying as gamma $(=0.25)$ distribution. In all methods, both the replicase and ORF8/3'UTR sequences were analyzed separately, and combined.

\section{RESULTS}

RT-PCR detection of LChV-1. Amplicons of the expected sizes of $274 \mathrm{bp}$ for the ORF8/3'UTR region (Fig. 1A) or 300 bp for the segment of the replicase gene (Fig. 1B) of LChV-1 were reproducibly obtained with the total RNA extracts prepared using the commercial kit (lanes 3, 4, $6,7,8$, and 9), with RNA extracted from purified virus preparation (lane 2) and with dsRNA (lane 5) using the two pairs of primers. Samples in lanes 2 through 5 were from orchard WAYa1 in Yakima County, samples in lanes 6 through 8 were from orchard WACh1 in Chelan County, and the sample in lane 9 was amplified from isolate 98FI10R2. There were no RT-PCR products observed with the water as template control (Fig. 1) or with total RNA extracted from uninfected sweet cherry (not shown).

There was an apparent difference in the relative intensity of the products between the two primer pairs. The PCR products amplified using the repl-1 primers (Fig 1B) were more intense and more uniform than those generated with the $3 p-1$ primers despite using the same total concentrations of RNA of each isolate as template for the two reactions. Extracts from different trees within the same orchard yielded different amounts of amplicons generated with primer pair $3 p-1$ and measured by intensities in stained gels (Fig. 1A, lanes 6 to 8). Two isolates, WACH1b (Fig. 1A, lane 6, weak amplification) and WACh1b (Fig. 1A, lane 8, strong amplification) were sequenced to determine whether they represented two distinct genotypes within one orchard (see below). Two LChV-1 isolates considered in this study, PALal from PA, and WAYa2 from WA, failed to yield detectable products with the $3 p-1$ primers while producing robust amplification with the repl-1 primers; these two isolates are also very closely related in the replicase region (Fig. 2; see below). Although both virus purification and dsRNA methods produced suitable, perhaps superior, template for RT-PCR, the kit-based total RNA extraction proved most useful and timeefficient. Thus, we used the repl-1 primers for RT-PCR with total RNA template for detection of LChV-1 in field samples.

Sequence variability of $\mathrm{LChV}-1$ isolates. Isolates of $\mathrm{LChV}-1$ were obtained from widely disparate sources from both Washington (Table 1) and other states and countries (see Materials and Methods). When template from these isolates were amplified with the repl-1 or the $3 p-1$ primers, amplicons of the predicted size were observed, with the exception of isolates PALa1 and WAYa2 that did not yield amplification products with the $3 p-1$ primers. The amplicons produced were sequenced

Table 1. Detection of Little cherry virus 1 (LChV-1) and Little cherry virus 2 (LChV-2) in symptomatic trees of five Washington orchards ${ }^{\mathrm{a}}$

\begin{tabular}{lccc}
\hline & \multicolumn{3}{c}{ Trees with } \\
\cline { 2 - 4 } Orchard designation and county & $\begin{array}{c}\text { LChV-1 } \\
\text { only }\end{array}$ & $\begin{array}{c}\text { LChV-2 } \\
\text { only }\end{array}$ & $\begin{array}{c}\text { Both LChV-1 } \\
\text { and LChV-2 }\end{array}$ \\
\hline WAYa1, Yakima County & $4 / 4$ & $0 / 4$ & $0 / 4$ \\
WAYa2, Yakima County & $3 / 13$ & $6 / 13$ & $0 / 13$ \\
WACh1, Chelan County & $2 / 10$ & $3 / 10$ & $1 / 10$ \\
WACh2, Chelan County & $0 / 3$ & $0 / 3$ & $1 / 3$ \\
WAGr1, Grant County & $10 / 18$ & $0 / 18$ & $0 / 18$ \\
Total positives/total assayed & $19 / 48$ & $9 / 48$ & $2 / 48$ \\
\hline
\end{tabular}

a Total RNA extracts were tested for LChV-1 and LChV-2 in separate reverse-transcription polymerase chain reactions in all cases. 
and they all corresponded to LChV-1. Further analysis of the sequences indicated that the isolates segregated into several distinct clades (Fig. 2) with varying degrees of nucleotide sequence divergence. Notably, replicase sequences from two Eurasian isolates (98FI10R2 and UW1.2) exhibited 18 to $21 \%$ nucleotide sequence divergence in pairwise comparisons with nine North American (NA) isolates. Among the NA isolates, replicase sequence divergence ranged from 0.4 to $10.9 \%$ in pairwise comparisons. Sequence divergence within the 232-nt region of the ORF8/3'UTR ranged from 9.9 to $12.6 \%$ in pairwise comparisons between seven NA

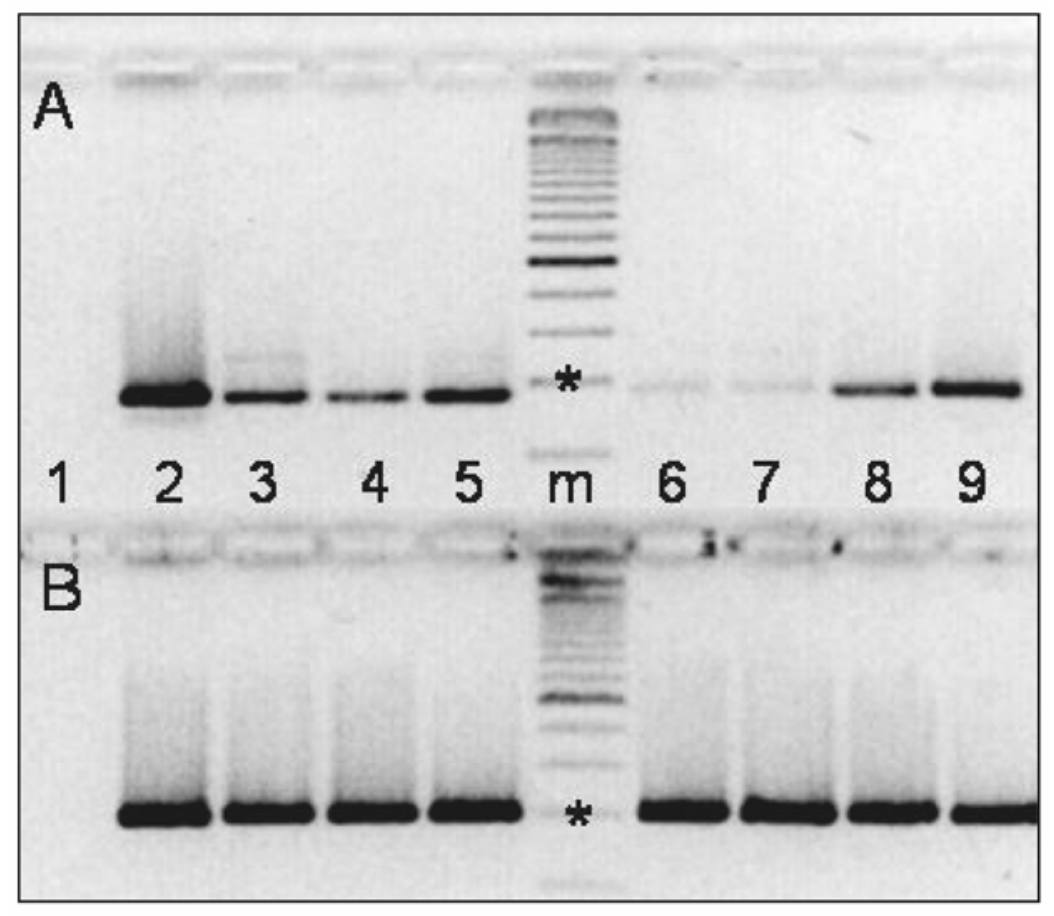

Fig. 1. Agarose gel electrophoresis of one-step reverse transcription polymerase chain reaction (RTPCR) products amplified from three methods of preparing RNA templates from Little cherry virus 1 (LChV-1)-infected tissues: lane 1, negative control (water as template); lane M, 100-bp DNA ladder (Invitrogen) with the 300-bp band highlighted with *; lane 2, RNA extracted from purified virus preparation as template; lane 5, RNA extracted from dsRNA as template; lanes 3, 4, 6, 7, 8, and 9, kitextracted total RNA. RT-PCR employed two pairs of primers: A, Primers from the 3-prime region (3p-1) produced a 274-bp product, and B, Primers for the replicase region (repl-1) produced a 300-bp product. Samples in lanes 2 through 5 were from orchard WAYa1 in Yakima County, WA; samples in lanes 6 through 8 were from orchard WACh1 in Chelan County, WA; and the sample in lane 9 was from an isolate received from Turkey (98FI10R2). Note the relatively uniform intensity of the PCR products on $\mathbf{B}$ compared with $\mathbf{A}$, despite using identical template samples for each.
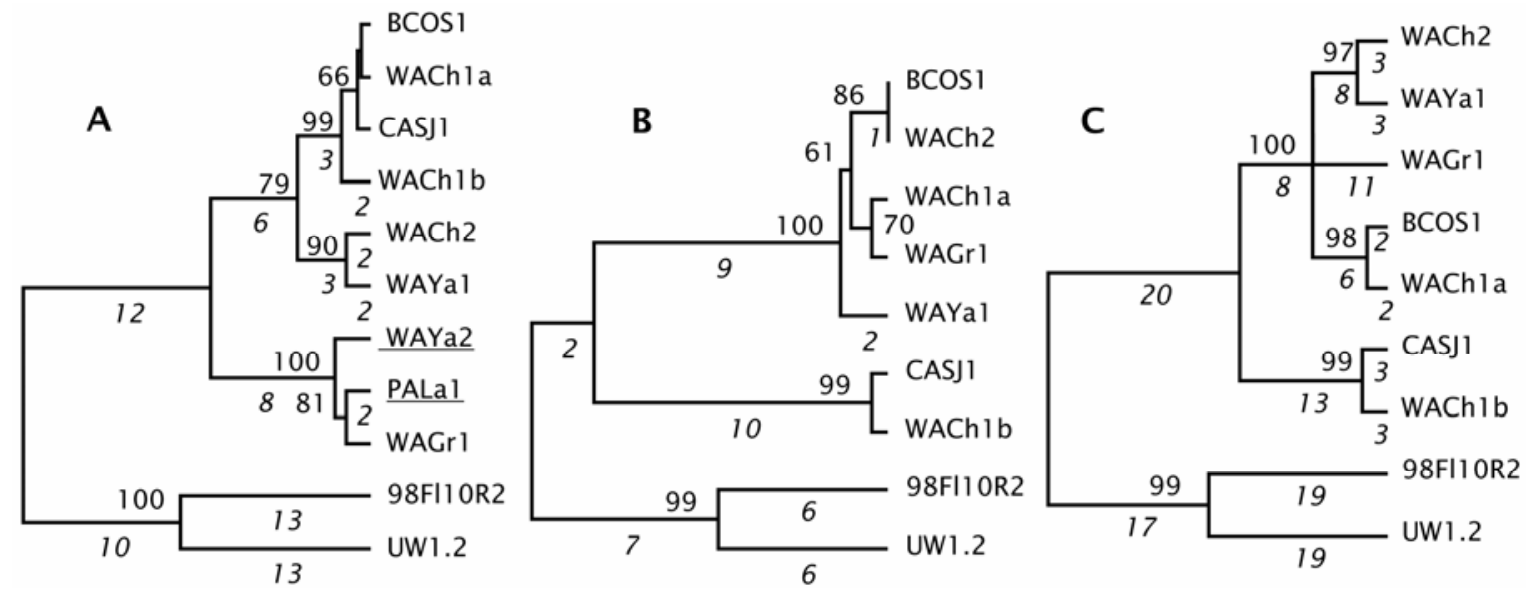

Fig. 2. Cladograms illustrating hypothetical phylogenetic relationships derived from the nucleotide (nt) sequence variation found in the replicase and 3-prime regions among Little cherry virus 1 (LChV-1) isolates from sweet cherry collected in various regions of the world. Cladograms were created using the neighbor-joining algorithm implemented in MEGA3 and show both branch lengths in proportion of total sequence difference (italics) and bootstrap reliability estimates; branch lengths along the path between two isolates can be added to estimate pairwise sequence difference. Cladograms were derived from a 240-nt sequence within the replicase gene (A), a 232-nt sequence extending from the 3' end of ORF8 into the 3'UTR (B), and using the 472 nt from both sequences (C). Similar branching orders and statistical support were seen with other methods of phylogenetic analysis. 
the same reaction. However, this multiplex system is not as sensitive as the amplification of each virus alone. Specifically, the multiple infections described in the field study below were not detectible with the multiplex protocol; thus, this approach should be used cautiously.

Detection of LChV-1 and LChV-2 in field samples. The one-tube, single-virus RT-PCR was able to detect LChV-1 and LChV-2 in total RNA from leaf samples collected throughout Washington State (Table 1). Both LChV-1 and LChV-2 primer sets produced the appropriate amplicons with up to 1:1000 dilution of the total RNA in simplex RT-PCR reactions used here (data not shown). Both viruses were present in multiple sweet cherry orchards, and were found in mixed infections in single trees in two separate orchards (Table 1).

\section{DISCUSSION}

These studies provide the first demonstration of LChV-1 and LChV-2 associated with LChD in Washington State and also show that LChV-1 occurs in California and Pennsylvania, further extending the geographic distribution of these two viruses in North America. The five orchards in Washington where samples were collected occur in the main production areas of Washington State and initially were visited because of small fruit symptoms severe enough that it was not profitable to harvest affected trees. It is likely that the number of orchards in which the viruses associated with $\mathrm{LChD}$ are found will increase as awareness of the disease increases. The presence of these viruses may present a challenge to the sustainability of sweet cherry production in Washington State. However, a reliable RT-PCR protocol to detect both $\mathrm{LChV}-1$ and $\mathrm{LChV}-2$ presented here (also $4,14,29,32,36)$ and existing control methods for the apple mealy bug and other potential vectors should preclude a reoccurrence of the widespread and rapid dissemination of $\mathrm{LChD}$ reported during the 1930s to 1950s in Western North America $(1,3,32,37)$. An insect vector of LChV-1 has not yet been determined.

Our results confirm and complement other methods of RNA preparation from woody plants for the detection of RNA viruses by RT-PCR $(17,18,20,25)$. The results also highlight the critical nature of the amplification primers in this endeavor. Multiple primer pairs based on the published sequence of the LChV-1 were tested on several virus isolates but failed to yield reliable amplification. These included seven primer pairs from the coat protein, one primer pair from the duplicate coat protein, and two primer pairs from the helicase/replicase transition region (K. C. Eastwell, unpublished data). The $3 p-1$ primers have been used to characterize various $\mathrm{LChV}-1$ isolates in Canada $(1,31,32)$ and in Europe (36). Although this primer set may be applicable for testing a wide spectrum of naturally occurring LChV-1 variants (36), the repl-1 primer pair performed more reliably in our hands for detecting various isolates, including 10 from North America and 2 from Eurasia. The observed variation in amplicon intensity for LChV-1 isolates amplified with the $3 p-1$ primers and our inability to amplify the PAla1 and WAYa2 isolates (which fall into a distinct clade for the replicase region sequence; Fig. 2) with the $3 p-1$ primers, despite multiple attempts, likely was caused by primer sequence mismatch among isolates. This hypothesis needs to be verified by sequencing through the existing primer regions in selected isolates. Given the more reliable behavior of the repl-1 primers, this effort may not be justified. Similarly, variable success was reported with four pairs of primers used to detect two sweet cherry flexiviruses, Cherry green ring mottle virus and Cherry necrotic rusty mottle virus (17), and also may be explained by idiosyncratic variation in isolates at the priming region. However, given the high sequence variation we observed in the replicase region, at least as high as that observed in the ORF8/3'UTR, it is possible that the repl-1 primers may not always be reliable. Coincidently, the LChV-2-specific primers used also were designed from a region of the replicase gene from the "LC5" isolate from Canada (32).

Sequence analyses of the LChV-1 replicase region for different isolates exposed significant variation among isolates. The two sequences from Eurasia (98FI10R2 and UW1.2) segregate on a single branch but are still quite distinct from one another, exhibiting 11 and 5\% nucleotide sequence divergence in the replicase and ORF8/ 3'UTR segments, respectively. The NA isolates show twice as much nucleotide sequence divergence as the two Eurasian isolates, differing by roughly $20 \%$ at the replicase and $10 \%$ at the ORF8/3'UTR segments, respectively. The sequences of isolates of LChV-1 from North America also exhibit significant sequence divergence from one another, namely 0 to $10 \%$ in both sequenced regions, and, curiously, two of the most diverged NA isolates were found in the same orchard (WACH1a and WACH1b; Fig. 2). The relationships derived from nucleotide sequence differences (Fig. 2) suggest that the NA LChV-1 isolates are unlikely to have been derived from either Eurasian isolate. Further, the discovery of isolates displaying significant sequence variation from different trees in a single orchard and no observable association of nucleotide sequence divergence with spatial isolation over all NA isolates suggest that multiple introductions of LChV-1 may have occurred within the commercial sweet cherry industry in NA. If the latter is true, it may reflect the difficulty in detecting LChV-1 by biological indexing $(6,16)$.
The one-step RT-PCR protocols described here provide a useful, albeit costly, tool for diagnosis of the causal agent of little cherry symptoms. Fruit and foliar symptoms alone are unreliable for diagnosis of LChD because factors such as winter damage, zinc deficiency, and a heavy fruit crop often result in cherry fruit that are smaller than normal $(3,21,37)$. Similarly, age of the affected plant, poor soil, and other pathogens, including the Western-X phytoplasma, may induce similar symptoms. The one-step RT-PCR system has been used for detection of both LChV-1 and LChV-2 $(14,29)$ and has proved less cumbersome and may significantly reduce the risk of cross contamination than twostep RT-PCR described by others $(11,36)$. Similar results were shown (17) for the detection of two cherry flexiviruses in sweet cherry by the one-step plate trap RTPCR. The repl-1 primers designed from the replicase region appear to improve the reliability of this tool for diagnosis of LChV-1, at least for the NA isolates. With sensitivity up to $1: 1000$ dilution of the total RNA templates, this assay strengthens efforts to produce virus-free Prunus spp. germplasm $(2,21,28)$.

Biological indexing for the viruses of $\operatorname{LChD}(6,16)$ requires a constant supply of healthy indicator plants and ample area for maintaining inoculated trees. Indexing also takes several weeks to months for effects on the indicator host to be noticeable $(6,16,28)$. In contrast, the one-step RTPCR can be applied for a rapid preliminary evaluation of virus-status of sweet cherry so that appropriate actions can be initiated preemptively while biological indexing proceeds and provides confirmatory results. Development of monoclonal antibodies for similarly rapid, inexpensive, and potentially more sensitive detection of both viruses is ongoing.

\section{ACKNOWLEDGMENTS}

PPNS \#0445, Department of Plant Pathology, College of Agricultural, Human, and Natural Resource Sciences Agricultural Research Center Project No. WNP00290, Washington State University, Pullman, WA, 99164-6240, USA. This work also was supported in part by grants from the Washington State Tree Fruit Research Commission and the Horticulture Research Institute. We thank S. Lambert for maintaining virus isolates in the screenhouse; R. Welliver, Pennsylvania State Department of Agriculture, and $\mathrm{M}$. Bernardy, Agriculture \& Agri-Food Canada, for supplying infected material from Pennsylvania and British Columbia, respectively; J. Crosslin (United States Department of AgricultureAgricultural Research Service [USDA-ARS], Prosser, WA), S. Garczynski (USDA-ARS, Wapato, WA), and H. Pappu (Department of Plant Pathology, Washington State University, Pullman) for reviews of earlier drafts of this manuscript; and S. M Gray, (USDA-ARS, Department of Plant Pathology, Cornell University, Ithaca, NY) for helpful editorial assistance.

\section{LITERATURE CITED}

1. Bernardy, M. G., French, C. J., and Milks, M. 2002. New variant of Little cherry virus associated with little cherry disease of sweet cherry 
in British Columbia, Canada. Plant Dis. 86:1406.

2. Diekmann, M., and Putter, C. A. J. 1996, FAO/IPGRI Technical Guidelines for the Safe Movement of Germplasm, No. 16, Stone Fruits. FAO, International Plant Genetic Resources Institute, Rome.

3. Eastwell, K. C. 1997. Little cherry disease-In perspective. Pages 143-151 in: Filamentous Viruses of Woody Plants. P. L. Monette, ed. Research Signpost, Triandrum, India.

4. Eastwell, K. C., and Bernardy, M. G.. 1996. Association of high molecular weight doublestranded RNA with little cherry disease. Can. J. Plant Pathol. 18:203-314.

5. Eastwell, K. C., and Bernardy, M. G.. 2001. Partial characterization of a closterovirus associated with apple mealybug-transmitted little cherry disease in North America. Phytopathology 91:268-273.

6. Eastwell, K. C., Bernardy, M. G., and Li, T. S. C. 1996. Comparison between woody indexing and a rapid hybridization assay for the diagnosis of little cherry disease in cherry trees. Ann. Appl. Biol. 128:269-277.

7. Felsenstein, J., and Churchill, G. A. 1996. A hidden Markov model approach to variation among sites in rate of evolution. Mol. Biol. Evol. 13:93-104.

8. Fry, P. R. 1970. Little cherry virus in New Zealand. N. Z. J. Agric. Res. 13:111-118.

9. Hansen, M. 2000. Northwest cherry production could double. Good Fruit Grow. Wash. Hortic. Assoc. 51:44-45.

10. Huelsenbeck, J. P., and Ronquist, F. 2001. MRBAYES: Bayesian inference of phylogeny. Bioinformatics 17:754-755.

11. Isogai, M. Aoyagi, J., Nakagawa, M., Kubodera, Y., Sato, K., Katoh, T., Inamori, M., Yamashita, K., and Yoshikawa, N. 2004. Molecular detection of five cherry viruses from sweet cherry trees in Japan. Phytopathol. Soc. Jpn. 70:288-291.

12. Jelkmann, W., Fechtner, B., and Agranovsky, A. A. 1997. Complete genome structure and phylogenetic analysis of little cherry virus, a mealybug-transmissible closterovirus. J. Gen. Virol. 78:2067-2071.

13. Keim-Konrad, R., and Jelkmann, W. 1996. Genome analysis of the $3^{\prime}$-terminal part of the little cherry disease associated dsRNA reveals a monopartite clostero-like virus. Arch. Virol. 141:1437-1451.

14. Komorowska, B., and Cieslinska, M. 2004. First report of cherry virus A and little cherry virus-1 in Poland. Plant Dis. 88:909.

15. Kumar, S., Tamura, K., and Nei, M. 2004. MEGA3: Integrated software for Molecular
Evolutionary Genetics Analysis and sequence alignment. Briefs Bioinf. 5:150-163.

16. Legrand, G., and Verhoyen, M. 1986. Use of different methods to detect little cherry disease in ornamental trees. Acta Hortic. 193:283-289.

17. Li, R., and Mock, R. 2005. An improved reverse transcription-polymerase chain reaction (RT-PCR) assay for the detection of two cherry flexiviruses in Prunus spp. J. Virol. Methods 129:162-169.

18. MacKenzie, D. J., McLean, M. A., Mukerji, S., and Green, M. 1997. Improved RNA extraction from woody plants for the detection of viral pathogens by reverse transcription polymerase chain reaction. Plant Dis. 81:222-226.

19. Martelli, G. P., Agranovsky, A. A., Bar-Joseph, M., Boscia, D., Candresse, D. T., Coutts, R. H. A., Dolja, V. V., Falk, B. W., Gonsalves, D., Hu, J. S., Jelkmann, W., Karasev, A. V., Minafra, A, Namba, S., and Vetten, H. J. 2005. Family Closteroviridae. Pages 1077-1087 in: Virus Taxonomy: Eighth Report of the International Committee on Taxonomy of Viruses. C. M. Fauquet, M. A. Mayo, F. Maniloff, U. Desselberger, L. A. Ball, eds. Elsevier Academic Press, San Diego, CA.

20. Nassuth, A., Pollari, E., Helmeczy, K., Stewart, S., and Kofalvi, S. 2000. Improved RNA extraction and one-tube RT-PCR assay for simultaneous detection of control plant PNA plus several viruses in plant extracts. J. Virol. Methods 90:37-49.

21. Nemeth, M. 1986. Virus, Mycoplasma and Rickettsia Diseases of Fruit Trees. Martinus Nijhoff Publishers and Akademiai Kiado, Budapest.

22. Raine J., McMullen, R., and Forbes, A. 1986. Transmission of the agent causing little cherry disease by the apple mealybug Phenacoccus aceris and the dodder Cuscuta lupuliformis. Can. J. Plant Pathol. 8:6-11.

23. Reeves, E. L., and Cheney, P. W. 1963. Flowering cherries as symptomless hosts of Little cherry virus. Phytopathol. Mediterr. 2:184190.

24. Reeves, E. L., Cheney, P. W., and Milbrath, J. A. 1955. Normal appearing Kwanzan and Shiro-fugen Oriental flowering cherries found to carry a virus of the Little cherry type. Plant Dis. 39:725-726.

25. Rott, M. E., and Jelkmann, W. 2001. Characterization and detection of several filamentous viruses of cherry: adaptation of an alternative cloning method (DOP-PCR), and modification of an RNA extraction protocol. Eur. J. Plant Pathol. 107:411-420.

26. Rott, M. E., and Jelkmann, W. 2001. Detection and partial characterization of a second clos- terovirus associated with little cherry disease, Little cherry virus-2. Phytopathology 91:261267.

27. Rott M. E., and Jelkmann, W. 2005. Little cherry virus-2: sequence and genomic organization of an unusual member of the Closteroviridae. Arch. Virol.150:107-123.

28. Rowhani, A., Uyemoto, J. K., Golino, D. A., and Martelli, G. 2005. Pathogen testing and certification of Vitis and Prunus species. Annu. Rev. Phytopathol. 43:261-278.

29. Rybak, M., Kountrias, A., Eppler, A., Jelk mann, W., Heinze, C., and Adam, G. 2004. Improvement of RT-PCR based detection of two closteroviruses associated with little cherry disease in sweet cherries. J. Phytopathol. 152:65-68.

30. Sambrook, J., Fritsch, E. F. and Maniatis, T. 1989. Molecular Cloning: A Laboratory Manual, 2nd ed. Cold Spring Harbor Laboratory, Plainview, NY

31. Theilmann, J., Mozafari, J., Reade, R., Wu, Z., Xie, W., Jesperson, G., Bernardy, M., Eastwell, K. C., and Rochon, D. 2002. Partial nucleotide sequence and genome organization of a Canadian isolate of Little cherry virus and development of an enzyme-linked immunosorbent assay-based diagnostic test. Phytopathology 92:87-98

32. Theilmann, J., Orban, S., and Rochon, D. 2004. High sequence variability among little cherry virus isolates occurring in British $\mathrm{Co}-$ lumbia. Plant Dis. 88:1092-1098.

33. Thompson, J. D., Gibson, T. J., Plewniak, F. Jeanmougin, F., and Higgins, D. G. 1997. The ClustalX windows interface: flexible strategies for multiple sequence alignment aided by quality analysis tools. Nucleic Acids Res. 24:4876 4882.

34. USDA-National Agricultural Statistics Service. 2006. Sweet cherries: bearing acreage, yield production, and utilization by state and United States, 2003-2005. Page 36 in: Noncitrus Fruits and Nuts, 2005 Summary. USDANASS, July 2006

35. Uyemoto, J. K., and Scott, S. W. 1992. Important diseases of Prunus caused by viruses and other graft-transmissible pathogens in California and South Carolina. Plant Dis. 76:5-11.

36. Vitushkina, M., Fechtner, B., Agranovsky, A., and Jelkmann, W. 1997. Development of RTPCR for the detection of little cherry virus and characterization of some isolates occurring in Europe. Eur. J. Plant Pathol. 103:803-808.

37. Welsh, M. F., and Cheney, P. H. 1976. Little cherry. Pages 231-237 in: Virus Diseases and Noninfectious Disorders of Stone Fruits in North America. U.S. Dep. Agric. Handb. 437. 